\title{
Higher Education Policy In The United Kingdom - Reformation or Dissolution?
}

\author{
JOHN D. DENNISON*
}

\section{INTRODUCTION}

The purpose of this paper is to analyse those imminent and potent changes within higher education in the United Kingdom which are to follow the introduction of the government's Education Reform Bill of 1987 (NOTE 1). This legislation, referred to popularly (and not without wry amusement) as GERBIL, is designed to bring major changes in funding policy, governance, and conditions of appointment for faculty in the universities, polytechnical institutes and selected colleges in Britain.

While there are fundamental differences between the structure and organization of tertiary education in Britain and Canada, it is useful to ponder several imperatives which reflect government policy in the United Kingdom and which are strikingly similar to many of the policy thrusts instituted by the Mulroney government in the past four years. It is for this reason that the Education Reform Bill, viewed from a Canadian perspective, provides an intriguing vision of the future of higher education which seems to be much more relevant to the Canadian context than might first appear.

British higher education enjoys both the advantages and disadvantages of having to relate primarily to one level of government in Westminster (NOTE 2). Nevertheless, there are important differences in the management and structure of the system in Scotland, Wales, and Northern Ireland, quite apart from critical variations in roles and functions between universities and polytechnics. As in Canada, the relationship in Britain between institutions of higher education and elected governments, local or national, is an important factor in how these institutions exercise fiscal and curricular autonomy, conduct research, and establish educational priorities.

In this regard, Oxford's Professor Donald Dworkin notes that, although the recent initiatives taken by the Thatcher government in the United Kingdom might appear on the surface to be about economics and efficiency, they really represent "an ideological battle between two strikingly different versions of the role of universities in a democracy" (Dworkin, 1988). 
The first of the two visions to which Dworkin was referring, the integrationist model, would place the universities within the orbit of the civil service, and as such, subject them to policies set by either government or the marketplace. Conversely, the second vision would preserve the essentially independent role for the universities, ensuring their relative autonomy in matters of governance and budgetary allocation.

Before commenting upon those specific aspects of the Education Reform Bill which are most relevant and meaningful within Canadian academic traditions, it would be helpful to review some of the recent and important landmarks in British higher education which have led to the current state of affairs.

\section{THE ROAD TO THE REFORM BILL}

Prior to World War II higher education in the United Kingdom was for most people simply unattainable. Two thirds of the population completed school at 14 and less than four percent of the relevant age cohort found a place in a university. The Education Act of 1944 provided a major impetus for change. Local authorities were able to provide financial awards for university study and many highly talented, but less affluent, individuals were able to continue their education (NOTE 3).

The Robbins Report of 1963 became the catalyst for greater democratization of educational opportunity by recommending an increase of 350,000 places in institutions of higher education between 1963 and 1981, with a building program to match the increased demand. The Robbins intent was clear, "courses of higher education should be available for all those who are qualified by ability and attainment to pursue them and who wish to do so" (Robbins, 1963).

British governments of all political flavors sustained the Robbins theme during the sixties and early seventies. Further opportunities were created by the formal establishment of the "binary system" and the Open University (NOTE 4). The binary system involved the addition (by redesignation of existing colleges) of thirty polytechnics in England and Wales, which, while under the aegis of local education authorities, were charged with providing a second stream of post-high school and degree level courses. Alongside them were the central institutions in Scotland, directly controlled by the Scottish Office of Government, and eventually thirteen in number, five of which being comparable to the polytechnics in their range of work. By 1980, higher education courses, involving a percentage of the student body varying from $1 \%$ to $100 \%$, also existed in some 400 other institutions. In consequence, participation rates reached 14 percent, with an accompanying increase in the numbers of mature and part-time learners.

Inevitably, the financial appetities of the two systems, within a period of inflation and fiscal uncertainty during the late 1970's, generated concerns from government authorities. However, it was the period commencing in 1979 which ushered in severe financial hardship. The Conservative administration, elected on a policy of restraint in the public sector, introduced reductions in recurrent grants 
to universities in the order of 10 percent during the 1981-84 period. These reductions, administered through the Universities Grants Committee, were widely selective with respect to the universities, and resulted in variable limitations upon the number of student places made available. In a similar vein, government imposed limits upon the expenditure by local authorities upon the other component of the binary system and comparable reductions occurred.

The Education Reform Bill, however, has introduced changes which are considerably more fundamental than mere budgetary reductions and it is important to note some of the more prominent public documents which preceded the bill and foreshadowed its philosophy.

\section{THE JARRATT REPORT: THE EFFICIENCY OF THE UNIVERSITIES}

In April 1984, the Committee of Vice-Chancellors and Principals established a group under the chairmanship of Sir Alex Jarratt, Chancellor of Birmingham University, to report on ways to improve efficiency in the universities (Jarratt, 1984). While acknowledging the historical excellence of British universities, the Jarratt Report recommended several ways to improve their efficiency. The latter included a number of corporate management approaches, explicit recognition of the Vice-Chancellor as Chief Executive of the institution, the development of reliable and consistent performance indicators, and the need for long term strategic planning. The Report noted, inter alia, the constraint upon institutional flexibility caused by the traditional practices of tenure.

While the Jarratt proposals may seem not to be particularly radical by Canadian experience, they posed serious challenges to certain British academics who value the "classic and autonomous model of the government of higher education", in which the notion of "managerialism" is particularly inappropriate (Kogan, 1988).

\section{THE NATIONAL ADVISORY BODY REPORT}

The National Advisory Body (NAB) was established in 1982 to advise government on the funding and operational needs of the second arm of the binary system, the polytechnics and colleges/institutes of higher education, generally referred to as "public sector" higher education. In 1985, a NAB committee, at the request of the Secretary of State for Education and Science, prepared a report entitled "Management for A Purpose" (Ball, 1986).

This report addressed the need for improved management of the public sector and produced a large number of recommendations. In general, the latter suggested ways in which better management could promote a more efficient and effective system. Planning, coordination of policy development, improved budgetary systems, and better accountability practices, all featured in the recommendations. Further, the Report suggested that the roles of the Local Education Authorities, as the bodies responsible for institutional governance, should be reviewed; that LEA's should retain strategic functions but delegate much greater autonomy to the 
colleges; and that the latter should, where appropriate, be given corporate status to manage their own affairs. Not surprisingly, the Report made no suggestion that the NAB itself should be abolished. It is also important to note that the Committee of Directors of Polytechnics had produced its own report on the future of their institutions and had recommended severing of all constitutional ties with the LEA's and the award of corporate status to the polytechnics.

\section{THE CROHAM REPORT AND THE UNIVERSITY GRANTS COMMITTEE}

Another influential report was one submitted by a committee, commissioned by government under the chairmanship of Lord Croham, which reviewed the role and function of the University Grants Committee (Croham, 1987). The UGC has served from 1919 as an advisory body on the allocation of the higher education grant to the various institutions. Its membership had been drawn almost totally from the academic world, and its advice had been almost universally followed.

The Croham Committee recommended significant changes. The UGC should become a formally incorporated body with a full-time Director General and staff, independent of government. Its composition should have broadly equal representation from academic and non-academic circles, and its Chairman should be an "eminent figure" with experience outside the academic world. Further, the UGC should have "unambiguous" power regarding conditions of grants to universities and require greater accountability from the latter as to the disposal of their fiscal allocations.

Another significant recommendation in the report was to urge the government to fund the system on a triennial basis, ensuring adequate time for planning necessary changes in the event of fiscal reduction.

\section{THE GOVERNMENT'S “WHITE” PAPER}

Finally, government thinking was revealed with the distribution of a "white paper", Higher Education: Meeting the Challenge, published prior to the 1987 election. The thrust of the paper was clear - higher education's links with the corporate world should be strengthened, while its contribution to economic growth was to be more fully asserted. Accessibility was to be linked to the need for highly qualified manpower, and a better balance between the needs of the economy and the needs of individuals would be established. The key themes of quality and efficiency would be enhanced by improvements in the management, performance, and accountability of the individual institutions.

The polytechnics and other major institutions of higher education were to be removed from the local authority control and placed under a UGC equivalent - the Polytechnic and Colleges Funding Council (PCFC). Again, the intent was to provide better management and responsiveness by the polytechnics to national economic needs. 
On the university side the UGC was to be replaced by a Universities Funding Council (UFC), structured in accordance with recommendations in the Croham report.

\section{THE EDUCATION REFORM BILL (1988)}

The Education Reform Bill is a very large and comprehensive piece of legislation of which only a small part is concerned with the higher education sector. Opposition from many quarters, particularly to the changes in the schools component, has been intense and vocal, although concern with certain aspects relating to higher education has also been strongly expressed. Nevertheless, the Bill has survived the Commons and the Lords, eventually receiving Royal Assent on July 29, 1988.

The comments which follow will focus upon those aspects which seem most relevant to the higher education community in Canada. In each case discussion is directed both to the Bill itself and to those policy statements which the government has published as interpretations and precursors to change in specific aspects of the system.

\section{Academic Tenure}

This legislation applies to all government funded universities and university colleges in Great Britain and effectively removes the status of academic tenure from all new academic appointments as from October, 1987. It will also apply to existing staff who accept new positions in their own, or other institutions.

The objective is to ensure that institutions have the power to terminate the appointment of academic staff for reasons of redundancy or financial exigency. In order to bring this change into effect commissioners will be empowered to make or amend the charters or acts upon which institutions have been established. Eventually, all such charters will contain equivalent references to conditions of academic appointments. Redundancy and financial exigency have both been defined and, in addition, reference is made to dismissal for "good cause", which refers to unsatisfactory performance of duties.

In discussing the tenure issue it is important to recognize a number of factors. While tenure has existed for many years in British universities only approximately half of the appointments of academic staff are explicitly categorized as tenured. Furthermore tenure, as it has been understood, has rarely if ever been contested in a court of law. The problem of tenure, however, appears to be viewed historically as one in which no tenured academic appointment could be terminated, irrespective of financial circumstances, the status of the program, or it seems, the performance of the individual. Viewed from a British perspective, the government's action is consistent with its vision of universities as institutions able to respond to economic needs and to changes in the corporate marketplace. Further, references to efficiency and quality of performance must be linked ultimately with the tenure issue. 
Predictably, concern over this legislation has centred around the need to preserve academic freedom and the traditional and well respected role of British academics as responsible critics, "intolerant of fashion, scientists driven by wonder not commerce, philosophers who challenge what everyone knows" (Dworkin, 1988). Substantial lobbies are reiterating the need for the Secretary of State to make full and explicit recognition of the importance of academic freedom, either in legislation, or within the individual charters which sustain the institutions.

Eventually, the intensive efforts of the universities and related organizations, particularly the Committee of Vice-Chancellors and Principals, were partly realized. The House of Lords, in its debate on Bill in July, 1988, supported a number of amendments, including the provisions to recognize academic freedom specifically in the legislation. This amendment was not subsequently overturned by the government in the Commons.

Could similar action by government, presumably at the provincial level, abolish academic tenure in Canada? Tenure in Canadian universities seems to be more directly and explicitly connected to academic freedom than it does in Britain. In Canada, procedures and provisions for staff reductions in the face of financial stress are negotiable between individual faculty associations and their administrations without the need for any government involvement. Conceivably, governments in Canada could introduce legislation concerning conditions of appointment by making amendments to university acts, although the prospect seems remote. Nevertheless, there is an important lesson to be learned from Great Britain. Universities which grow complacent in continuing to emphasize their roles as responsible critics of society and as centres of excellence in all aspects of their operation may well be vulnerable to those in power who fail to understand the need for intellectual and political independence of universities in a free society. Academic freedom may well grow more fragile in a world where little difference is perceived between universities and other elements of the public sector in the ways in which they all serve the economic priorities of the state.

\section{The Universities Funding Council}

As foreshadowed in a policy statement in 1987, government legislation proposed the abolition of the Universities Grants Committee and its replacement by the Universities Funding Council (UFC). Furthermore, payment of grants to institutions via the UGC would be superceded by a system of contracting of services between the UFC and the universities.

The new intermediary body is to be given statutory authority and expanded terms of reference to, "enquire into the extent and quality of teaching and research", and to review the role of universities in accordance with any guidance from the Secretary of State. While UFC would retain sole responsibility for the distribution of the total university grant, it would be expected to apply criteria based upon "judgements of value" and might be expected to fund specific university activities under explicit conditions. 
The concept of "contracting", which has aroused no small reaction from the academic community, is related to the expectation that universities will also attract fiscal contracts from private and other sources and "sharpen accountability" for their expenditure of public funds. How such contracts will be applied is, as yet, unclear. The Funding Council's membership will be divided equally between academic and non-academic representation. The Chairman will be from the latter constituency, while the full-time executive director will be from the former.

Much has been said, and will continue to be said, about the implications of these changes. There is also much which could be interpreted, even by the most optimistic observer of the higher education scene in Canada, as ominously relevant.

Intermediary bodies in Canadian provinces have been in decline for some years, but their powers, as originally propagated, have usually been transferred to government. The British proposal will give considerable authority to the UFC to demand fiscal and curricular accountability from the institutions and the extent to which the Council, with its new membership, will apply government policy, will be a subject of close scrutiny. The replacement of the term "grants" by "funding", in the title of the revised body, has an ominous implication for those who value the traditional autonomy of British universities. In like vein, the notion of "contracts" implies the application of much more precise control over the activities in which universities may engage.

It is for these reasons that defenders of university values, such as Professor Dworkin, have protested that universities in the United Kingdom are being brought into the "integrationist" model as noted earlier in this paper, in which they will be subject to the discipline of national goals and policies, determined by either government or the marketplace.

\section{The Polytechnics and Colleges Funding Council}

In tandem with the changes proposed for university governance, the polytechnics and selected colleges will also be brought within a new organizational structure. Government policy is to abolish the National Advisory Body and replace it with an independent corporate intermediary authority to be called the Polytechnics and Colleges Funding Council (PCFC). As a result, the institutions falling under the aegis of this Council will no longer be subject to the authority of Local Education Authorities (LEA).

Twenty nine polytechnics will be affected by the change, and with them all colleges with 350 or more full-time equivalent higher education students and more than $55 \%$ of FTE students in higher education courses. This category will include approximately 30 colleges.

The composition and powers of the PCFC will be essentially comparable to the proposed UFC. Again, the intent is to ensure greater accountability in fiscal and program matters from the institutions, and to encourage entrepreneurial activity from them by securing funds from outside government sources. 
The individual polytechnics and colleges under their new corporate status, will operate with both a governing and an academic board. A high degree of accountability will be expected from the governing boards, which will be broadly representative of both internal and external groups. The Secretary of State will retain certain powers regarding the initial selection of outside representatives.

While there has been considerably less reaction to the proposals regarding polytechnics and colleges than to those for universities, there are some significant implications. The role and responsibility of community groups in influencing postsecondary educational policy has clearly been reduced. It might be argued that good educational management is the ultimate objective but few deny that one overt political motive is the government's wish to undermine the power of unsympathetic local politicians.

Polytechnics and colleges in the United Kingdom are not directly comparable with community colleges in Canada in that they are much less directly responsible to their communities. Nevertheless, the trend towards centralization at the provincial level has been a Canadian phenomenon in the college sector for the last decade. As the financial climate becomes more oppressive and as central government exerts greater authority over the setting of priorities, it is inevitable that local powers will be further reduced. The question really remains as to whether the best interests and needs of diverse communities can be effectively served by the colleges under central, and sometimes remote, control. The British experience deserves to be carefully monitored.

\section{CONCLUDING COMMENTS}

The Education Reform Bill of 1988 in the United Kingdom has ushered in fundamental changes in the structure, governance and funding of higher education. Whether or not the role of higher education in its most essential relationship to government and society will, as some have stated, be changed forever, may not be clear for a generation. There is little doubt that the current political philosophy of Britain's Conservative administration is reflected directly in recent legislative initiatives.

Universities, polytechnics and colleges are to be regarded as state institutions, with varying degrees of independent authority, but at all times part of a public sector funded to sustain the economic and social priorities of the government. The current view is that not only should the higher education sector be held directly accountable for its fiscal support, it is neither desirable not appropriate for it to limit its funding sources to the public treasury, but it should engage in endeavors to secure alternative revenue. In fact, higher education should be "privatized" to a degree consistent with its public function.

With respect to the ultimate structure and control of higher education in the U.K., the creation of two intermediary bodies with statutary authority for each component of the binary system may well lead to even greater standardization of funding policy and practice. There is considerable conjecture among British 
academics that within a decade the binary system will become just one. In this event it may well be that major decisions, such as the funding of instructional program units, will be based upon standardized data irrespective of the institution in which the program occurs. Clearly, university budgets will be supplemented for research activity, but teaching may well be funded in accordance with a standard formula. If this occurs British institutions of higher education will operate under a controlled, itemized administration of institutional budgetary operations - hardly an appropriate policy to encourage creative academic within the educational enterprise!

The consequences of these policies are hard to predict, but one conclusion seems warranted. Higher education in the United Kingdom will no longer be the quasi-autonomous, internally judged (and, in the view of some, non accountable,) market-independent enterprise which has characterized its past.

The division of power and influence between federal and provincial governments in Canada with respect to their control over higher education could be seen as a permanent structural obstacle to the imposition of a British model such as the one described. Nevertheless, there are important lessons to be learned. The relation between governments and higher education institutions in Canada is a tenuous one. While there is more direct government influence over the operations of the college sectors, universities are by no means immune. Contemporary political jurisdictions have a tendency to intrude into the operation of any or all social institutions under the rhetoric of economic reform and the pursuit of market-driven priorities. The recent Canadian Job Strategy provides an interesting example of the way in which postsecondary institutions have lost direct fiscal support when their responsiveness to market needs has been questioned.

The British experience is one which invites careful study at a time when higher education in Canada is under review. There is much to be valued in the Canadian experience - and nothing should be taken for granted!

\section{NOTES}

1 The Bill was presented to Parliament in November 1987, and eventually received Royal assent as the Education Reform Act of 1988.

2 It is recognized that local education authorities have played a role in the governance of polytechnics and colleges. However, as will be described, this policy will change.

3 The wrilter is indebted to a publication by Maurice Kogan and David Kogan, The Attack on Higher Education, published by Kogan Page, 1983, for much of the background material.

4 Prior to the formalizing of the binary system, a second group of institutions, the Colleges of Applied Technology, offered a range of courses within the local authority sector. Those were later to be designated as "technological universities," e.g. Ashton, Salford. 


\section{REFERENCES}

Ball, C.J. (Chairman). Management for a Purpose, the Report of the Good Management Practice Group, National Advisory Body, March, 1987.

Croham, Lord (Chairman). Review of the University Grants Committee, London: Her Majesty's Stationary Office, 1987.

Dworkin, Ronald. "Conflicting Visions of the Role of Universities in a Democracy", The Independent, London, April, 1988.

Jarratt, Sir Alex (Chairman). Report of the Steering Chairman for Efficiency Studies in Universities, London: Committee of Vice-Chancellors and Principals, March, 1985.

Kogan, Maurice. "Managerialism in Higher Education", Speech (unpublished) to London University Institute of Education, March, 1988.

Kogan, Maurice and Kogan, David. The Attack on Higher Education, London: Kogan Page Ltd., 1983.

Robbins, Lord (Chairman). Report of the Committee on Higher Education, London: Her Majesty's Stationary Office, 1963.

Secretary of State for Education and Science, Higher Education: Meeting the Challenge, London: Her Majesty's Stationary Office, 1987. 